\title{
Maxillatumor - Richter-szindróma
}

\section{Cheekbone tumor - Richter syndrome}

\author{
Csomor Judit ${ }^{1, @}$, Györke Tamás ${ }^{2}$, Kiss Richárd $^{3}$, Mátrai Zoltán ${ }^{4}$ \\ ${ }^{1}$ Semmelweis Egyetem, I. sz. Patológiai és Kísérleti Rákkutató Intézet, Budapest \\ ${ }^{2}$ Semmelweis Egyetem, Nukleáris Medicina Központ, Budapest \\ ${ }^{3}$ Semmelweis Egyetem, I. sz. Patológiai és Kísérleti Rákkutató Intézet, \\ MTA-SE Lendület Molekuláris Onkohematológia Kutatócsoport, Budapest \\ ${ }^{4}$ Dél-pesti Centrumkórház Országos Hematológiai és Infektológiai Intézet, Budapest
}

(Beérkezett: 2019. március 1.; elfogadva: 2019. március 4.)
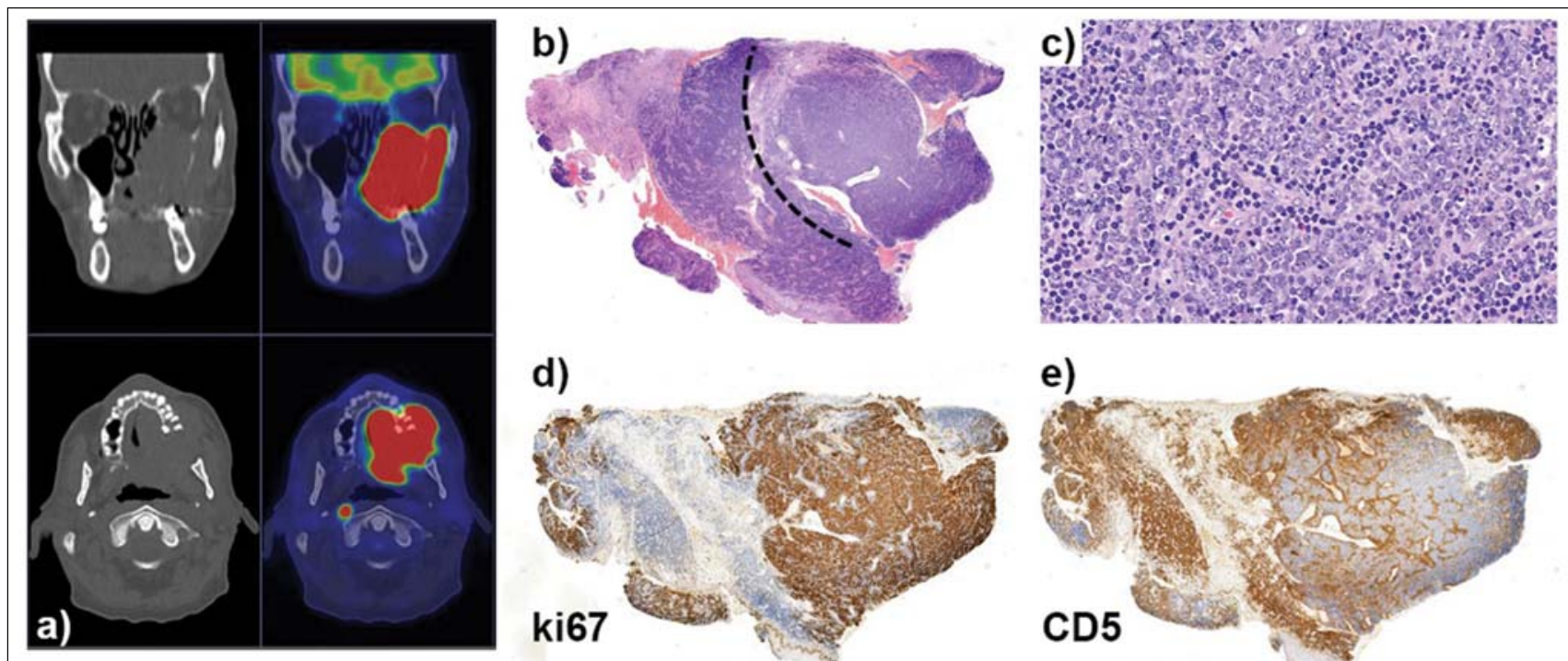

d)

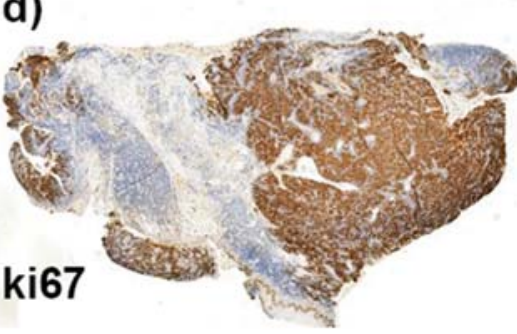

e)

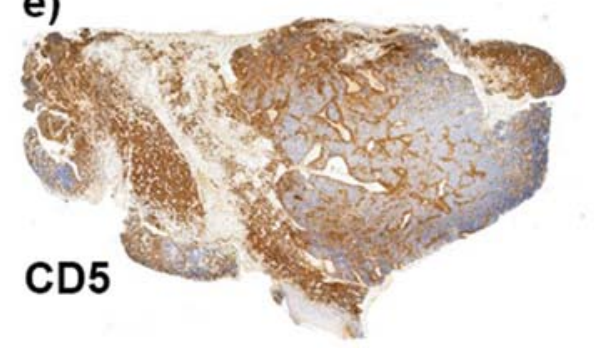

1. ábra. (a) Jobb oldali képek: coronalis síkú (felső sor) és transversalis síkú (alsó sor) csontablakos CT és fúzionált PET/CT. (b) A kép bal oldalán CLL, a kép jobb oldalán a transzformált tumor - DLBCL látható. HE $2 \times$ nagyítás. (c) A nagy nagyítású kép HE 40x - a DLBCL sejtképét mutatja. A nagysejtes részben a kisereket még 2-3 sejtsor lymphocyta, CLL sejtek szegélyezik. (d) A két tumor sejtképében, proliferációs rátájában és fenotípusában is különbözik. A proliferációs ráta markánsan, $10 \%$-ról közel 100\%-ra nőtt. (Ki67 immunreakció, 2×). (e) A kissejtes CLL rész CD5+, a transzformált nagysejtes tumor CD5-negatív. A CD5 reakció a perivasculáris CLL gyürüt kiemeli (CD5 immunreakció, $2 \times$ )

A 75 éves férfi beteg krónikus lymphoid leukémiáját (CLL) 2012-ben diagnosztizálták. Korábbi anamnézisében krónikus B-hepatitis szerepelt, amely miatt entecavirkezelésben részesült. A CLL diagnózisakor a betegség prognosztikus markerei a következőek voltak: mutált IgHV (88\% homológia), 12-es kromoszóma triszómia, $13 q$ deléció, illetve magas CD38 expresszió. A diagnózist követően a beteg kórtörténete a következően alakult: 2015-16-ban anémia és 170 G/L fehérvérsejtszám miatt leukoferezist követően két ciklus bendamustinterápiát kapott; 2017-18-ban R-bendamustinkezelésben részesült; a kemoimmunoterápiás kezeléseket követően 3-6 hónapos parciális remisszió volt elérhető.
Ezt követően 2018 októberében fogfájás, keményszájpad-daganat miatt történt fogászati ellátás és biopsziás mintavétel a tumorszövetből. Ekkor a beteg fehérvérsejtszáma 23 G/L, vérlemezke száma 298 G/L, LDH szintje $625 \mathrm{U} / \mathrm{L}$ volt. A biopsziás minta szövettani vizsgálata során Richter-szindróma igazolódott. A mintában kettős daganat volt megfigyelhető, elkülönülő területeken CLL és diffúz nagy B-sejtes limfóma (DLBCL) (1. ábra b)-c)). $\mathrm{Az}$ utóbbi, high grade komponens CG fenotípusú volt, CD5-, CD23- és bcl2-negativitással, továbbá közel 100\%os proliferációs rátával és 70\%-os c-Myc-expresszióval $(1$ ábra d)-e)). A FISH vizsgálat során normális c-Myc, BCL2 és BCL6 jelrendszer ábrázolódott. Disszekció után

\footnotetext{
@ Levelezési cím: Csomor Judit, Semmelweis Egyetem, I. Patológia és Rákkutató Intézet, 1085 Budapest, Üllői út 26.;

E-mail: jmj.csomor@gmail.com
} 
mindkét tumor IgHV- és TP53-mutációs státuszát elemeztük. A minta CLL és DLBCL frakciója egyaránt az IGHV343*01 gént tartalmazta, amely mindkét esetben a csíravonali génnel 88,54\%-os homológiát mutatott, azaz a két tumor klonálisan kapcsoltnak bizonyult. A TP53-szekvenálás mindkét tumor esetében vad típusú gén jelenlétét igazolta.

Az FDG PET/CT-vizsgálat bal sinus maxillarisban intenzíven halmozó, a sinus mindegyik falát destruáló, az orr- és szájüregbe terjedő $6 \times 6,5 \times 7 \mathrm{~cm}$-es lágyrésztumort mutatott ki, e mellett kiterjedt szupra- és infradiagfragmatikus nodális és csontvelőérintettséget igazolt (1. ábra a)).

A vizsgálatokat követően a beteg 2018 novembere és decembere során R-CHOP-kezelést és lokális irradiációt kapott, amely mellett a tumor gyors regressziót mutatott. December végén ibrutinibterápia indult, jelenleg (2019. február) a beteg panaszmentes, a CLL, illetve a DBLCL sem lokális, sem szisztémás aktivitást sem mutat.

A CLL transzformációjára egy régióban jelentkező nyirokcsomó-megnagyobbodás, extranodális tumor (esetünkben), B-tünetek, magas LDH- és kálciumszint utalhat. A biopszia optimális helyének kijelöléséhez, és a transzformáció kiterjedtségének megítéléséhez FDG PET/CT-vizsgálat ajánlott. A Richter-transzformáció diagnózisa minden esetben szövettani vizsgálaton alapul.

Richter-szindróma során a CLL az esetek mintegy 90\%-ban DLBCL-be transzformálódik, amely több mint 80\%-ban a megelőző CLL-lel azonos klónból származik, és azonos onkogén-mutációkat hordoz. E klonálisan kapcsolt forma prognózisa rossz, a tumor gyakran terápiarezisztens, átlagos túlélése 7-8 hónap. Az esetek fennmaradó, mintegy $20 \%$-ában a DLBCL klonálisan független, ennek a formának a prognózisa jobb, a de novo DLBCL-hez hasonló. A klonális kapcsolat fenotípusvizsgálatokkal nem határozható meg, ugyanis fenotípus klonálisan kapcsolt esetekben is eltérő lehet (esetünk). A prognózis szempontjából fontos információt az $I G H V$ génszekvenciák összehasonlításával kaphatjuk meg.

A Richter-esetek kb. 10\%-a Hodgkin-limfóma, elenyésző hányadban Burkitt-limfóma, limfoblasztos limfóma és T-sejtes limfóma is előfordul. A szövettani vizsgálat a transzformáció szövettani típusának meghatározásán kívül, a klinikailag hasonló tünetekkel járó betegség progresszió, agresszív CLL (összefolyó, nagy proliferációs centrumok) és szekunder, nem limfoid tumorok elkülönítése miatt is szükséges. Elkülönítő diagnosztikai nehézséget okozhat még a 12-es triszómiával járó CLL esetek egy része, melyben a vérkenetben, illetve csontvelőben is blastoid nagysejtek fordulnak elő.

Esetünkben a terápiát a korábban standardnak számító RCHOP-kezelés BTK-gátlóval történő kombinációja jelentette [1]; immun ellenőrzőpont-gátlók adásával is leírtak jó eredményeket [2]. A Richter-szindróma gyakoriságáról az adatok nagyon szórnak, 2-15\%-ra teszik. Még tisztázatlan, hogy az új terápiás lehetőségek csökkentik-e vagy növelik-e gyakoriságát [3]. Szubjektív tapasztalataink szerint az utóbbi időben többet diagnosztizálunk, DLBCL és a Hodgkin-limfóma is előfordult.

Esetünket morfológiai szépsége miatt mutattuk be, de „érzékenyítő” olvasmánynak is szántuk.

Nyilatkozat: A kézirat korábban más folyóiratban nem jelent meg, és máshova beküldésre nem került. A levelező szerző elolvasta a Hematológia és Transzfuziológia szerzői útmutatóját.

Érdekeltségek: A szerzőknek a közleményhez kapcsolódó közvetlen érdekeltségeik nincsenek.

Szerzői munkamegosztás: Cs. J., K. R.: a kézirat elkészítése; M. Z.: klinikai adatok összesítése; Cs. J., Gy. T.: az ábraanyag képeinek szerkesztése. A cikk végleges változatát valamennyi szerző elolvasta és jóváhagyta.

\section{Irodalom}

[1] Fischer A, Bastian S, Cogliatti S, et al. Ibrutinib-induced rapid response in chemotherapy-refractory Richter's syndrome. Hematol Oncol., 2018; 36: 370-371.

[2] Ding W, LaPlant BR, Call TG, et al. Pembrolizumab in patients with CLL and Richter transformation or with relapsed CLL. Blood, 2017; 129: 3419-3427.

[3] Allan JN, Furman RR. Current trends in the management of Richter's syndrome. Int J Hematol Oncol., 2018; 7(4): IJH09.

A cikk a Creative Commons Attribution 4.0 International License (https://creativecommons.org/licenses/by/4.0/) feltételei szerint publikált Open Access közlemény, melynek szellemében a cikk bármilyen médiumban szabadon felhasználható, megosztható és újraközölhető, feltéve, hogy az eredeti szerző és a közlés helye, illetve a CC License linkje és az esetlegesen végrehajtott módosítások feltüntetésre kerülnek. (SID_1) 